\title{
Danuta Grzesiak-Witek
}

\section{ORCID: 0000-0001-6959-9304}

Uniwersytet Jana Kochanowskiego w Kielcach

\section{Nauczyciel wobec dziecka z mutyzmem wybiórczym w wieku wczesnoszkolnym - wyłyczne do postępowania}

\author{
Teacher and Early School-age Child with Selective \\ Mutism. Guidelines for Proceedings
}

\begin{abstract}
SŁOWA KLUCZE ABSTRAKT
mutyzm wybiórczy, Mutyzm wybiórczy (SM) jest rozpoznawany u coraz większej grunauczyciel py dzieci. Jego istotą jest brak komunikowania się werbalnego, przy wczesnoszkolny, jednoczesnym wykluczeniu anatomicznego uszkodzenia narządów dziecko z mutyzmem mowy. Dla jednostki z mutyzmem rozpoczęcie nauki oraz edukacja w szkole, objawy w klasie I szkoły podstawowej to duże wyzwanie. Artykuł prezentuje i przyczyny przyczyny i objawy mutyzmu. Przedstawia także przebieg diagnozy mutyzmu, wytyczne dla nauczyciela oraz metody terapii dzieci obarczonych SM. Konkretne objawy mutyzmu wybiórczego oraz sposób funkcjonowania jednostek na niego cierpiących ukazano w oparciu o przypadki dwojga uczniów klas IIII szkoły podstawowej. Sprecyzowanie wytycznych dla nauczycieli edukacji wczesnoszkolnej, którzy w swojej klasie mogą spotkać ucznia z mutyzmem wybiórczym, stanowi istotny element tekstu. Brak wiedzy u wychowawcy na temat dziecięcego milczenia może przyczynić się do nieświadomego pogłębienia zaburzenia u podopiecznego. Właściwa postawa wobec dziecka z mutyzmem, stopniowanie wymagań, stworzenie przyjaznej atmosfery w klasie oraz zadbanie o pozytywne nastawienie rówieśników do kolegi cierpiącego na mutyzm to tylko niektóre z wytycznych, jakie pojawiają się w tekście. Nauczyciel edukacji wczesnoszkolnej jawi się tu także w roli łącznika pomiędzy logopedą a pozostałymi pracownikami szkoły.
\end{abstract}




\section{KEYWORDS ABSTRACT}

selective mutism, early school teacher, child with mutism at school, symptoms and causes of mutism, guidelines for teacher
Selective mutism (SM) is diagnosed in an increasing number of children. Its essence is the lack of verbal communication while anatomical damage to the speech organs has been excluded. For an individual with mutism, starting school and being educated in the first grade of primary school is a big challenge. This article presents the causes and symptoms of mutism. It also presents the course of diagnosis and methods of therapy for children with SM. Specific symptoms of selective mutism and functioning of individuals suffering from it are shown on the basis of the cases of two pupils from classes 1-3 of a primary school. Specifying guidelines for early education teachers, who may encounter a student with selective mutism in their class, is an important element of the text. Teachers' lack of knowledge about children's being silent may contribute to an unconscious worsening of the disorder in their pupils. The right attitude towards a child with mutism, grading of demands, creating a friendly atmosphere in the classroom, and ensuring a positive attitude of peers towards the child, are just some of the guidelines that appear in the text. Also, in the article the early education teacher is presented as a link between the speech therapist and other school employees.

\section{Wprowadzenie}

Czas rozpoczęcia edukacji w klasie pierwszej szkoły podstawowej to dla wielu dzieci ogromne wyzwanie połączone z lękiem przed nowym nauczycielem, kolegami oraz otoczeniem. Nie wszystkie dzieci radzą sobie z emocjami. Obecnie dodatkowo sytuację spotęgowała pandemia COVID-19, która towarzyszy społeczeństwu od 2020 roku. Dzieci, uczestnicząc w zdalnej formie nauczania, nie miały możliwości nabyć odpowiednich kompetencji społecznych oraz nie poznały zasad funkcjonowania w grupie rówieśniczej. Po tak długiej przerwie (ponad rocznej) czeka je kontakt z rówieśnikami i nauczycielem oraz konieczność sprostania wymaganiom edukacyjnym. Całą sytuację także nieświadomie zaostrzają rodzice, którzy sami odczuwają lęk przed pójściem dzieci do pierwszej klasy, a tym samym wzrostem obowiązków dla nich jako opiekunów.

Artykuł prezentuje zaburzenie zwane mutyzmem wybiórczym (selective mutism SM), jakie coraz częściej dotyka dzieci ${ }^{1}$. Uwaga zostanie skupiona na opisie jego

\footnotetext{
1 Badania przeprowadzone w USA i Izraelu wykazały częstość występowania mutyzmu wybiórczego na odpowiednio 0,71\% (USA) i 0,76\% (Izrael). Zaburzenie dotyka najczęściej dzieci w wieku od 2 do 5 lat, a objawy mutyzmu ustępują po około 8 latach. W przypadku braku wsparcia i zastosowania odpowiedniego leczenia deficyt może utrzymywać się znacznie dłużej (Rozenek et al. 2020: 337). Nie ma natomiast aktualnych danych na temat skali zjawiska mutyzmu wśród dzieci w Polsce.
} 
przyczyn i objawów oraz zakresu diagnozy i terapii dzieci w wieku wczesnoszkolnym, które są nim obarczone. Punkt ciężkości zostanie położony na wskazanie wytycznych dla nauczycieli edukacji wczesnoszkolnej, którzy w swojej klasie mogą spotkać ucznia z mutyzmem wybiórczym.

\section{Mutyzm - pojęcie, etiologia i objawy zaburzenia}

Mutyzm został po raz pierwszy opisany w literaturze naukowej przez niemieckiego badacza Adolfa Kussmaula w 1877 roku, który użył wówczas terminu aphasia voluntaria $\mathrm{w}$ stosunku do dzieci niemówiących, pomimo opanowania przez nie umiejętności komunikowania się słownego ${ }^{2}$. Jego istotą jest brak komunikowania się z otoczeniem przy wykorzystaniu kanału werbalnego. Przy czym należy od razu wykluczyć anatomiczne uszkodzenie narządów mowy (Bilikiewicz 2007: 706). U podłoża mutyzmu leży fobia społeczna, czyli lęk przed kontaktami społecznymi, w tym przed nawiązywaniem relacji, prowadzeniem rozmowy (Jóźwiak, Michałowicz 2001: 419). Uszczegóławiając obraz mutyzmu, należy przytoczyć jego definicję jako „brak lub ograniczenie mówienia (ekspresji oralnej) przy zachowaniu rozumienia mowy oraz możliwości porozumiewania się za pomocą pisma” (Janik 2012: 81).

Jednym z rodzajów mutyzmu jest mutyzm wybiórczy (selektywny), który w obowiązującej obecnie klasyfikacji ICD-10 oznaczany jest symbolem F94.0. Mutyzm selektywny odznacza się wybiórczością mówienia w określonych sytuacjach, miejscach ${ }^{3}$. Zazwyczaj jednostka milczy w nowych okolicznościach, natomiast w towarzystwie znanych osób komunikuje się werbalnie (Popek 2005: 142). Niemożność mówienia dotyczy wybranych sytuacji społecznych (przedszkole, szkoła). Dziecko w bezpiecznym otoczeniu (np. w domu) swobodnie rozmawia, a niekiedy jest wręcz gadatliwe (Cabała et al. 2016: 14). SM uznawany jest za typ zaburzeń funkcjonowania społecznego, mających początek w dzieciństwie albo w wieku młodzieńczym (Bystrzanowska 2018: 102). Piąta edycja klasyfikacji zaburzeń psychicznych wydana przez Amerykańskie Towarzystwo Psychiatryczne (DSM-V) umieszcza mutyzm selektywny w grupie zaburzeń lękowych i w takich kategoriach proponuje jego terapię́4.

\footnotetext{
2 Aphasia voluntaria, tj. afazja zamierzona, dotyczyła przypadków dzieci nieobarczonych żadnymi zaburzeniami organicznymi i rozwojowymi (Cabała et al. 2016: 9).

3 Terminu selective mutism (milczenie selektywne) w odniesieniu do prezentowanych zaburzeń użył psychiatra Moritz Tramer (1934).

4 W grupie zaburzeń lękowych poza mutyzmem selektywnym umieszczone zostały: specyficzne postacie fobii, napady paniki, separacyjne zaburzenia lękowe, lęk uogólniony, fobia społeczna, agorafobia (zob. Sajewicz -Radke 2016: 5-6).
} 
Niezwykle trudno wskazać jedną, konkretną przyczynę mutyzmu u danego dziecka, gdyż najczęściej jest to etiologia wieloczynnikowa (Cabała et al. 2016: 12). Czynnikami predysponującymi do wystąpienia zaburzeń mutystycznych są ogólna lękliwość dziecka, przypadki mutyzmu oraz zaburzeń lękowych w rodzinie 5 . Natomiast wśród czynników wywołujących mutyzm należy wymienić m.in.: negatywne doświadczenia dziecka (np. separacja lub rozwód rodziców, utrata bliskiej osoby), niewłaściwe reakcje otoczenia wobec dziecka (np. prześladowanie, wyśmiewanie się), świadomość wad/ zaburzeń mowy, brak poczucia bezpieczeństwa (np. częsta zmiana miejsca zamieszkania podyktowana sytuacją materialną rodziny). W przypadku działania na dziecko podatne psychicznie niekorzystnych czynników mogą wystąpić u niego zachowania mutystyczne, które zostaną utrwalone w sytuacji wystąpienia czynników podtrzymujących, tj.: niewłaściwych reakcji otoczenia na brak komunikacji werbalnej u dziecka w postaci nadopiekuńczości rodziców, zamiast szybkiej interwencji, izolowania dziec$\mathrm{ka}$, nieprawidłowego wzorca komunikacji w rodzinie ${ }^{6}$. Takie rozpatrywanie etiologii mutyzmu wybiórczego pozostaje w zgodzie ze stanowiskiem Julity Urbaniuk, iż SM jest zespołem heterogennym, uwarunkowanym biologicznie, genetycznie i społecznie (Urbaniuk 2008: 456). Bez wątpienia wszystkie powyższe czynniki należy wziąć pod uwagę, rozpatrując mutyzm u konkretnego dziecka. Niemniej jednak najbardziej aktualne badania zachowań mutystycznych wskazują, iż główną ich przyczyną są zaburzenia lękowe (Skoczek 2017a: 18). Dzieci lękowe reagują przesadnym niepokojem na sytuacje, które dla innych wydają się normalne, a mówienie w nieznanym otoczeniu w przypadku mutyzmu wybiórczego potęguje ten niepokój.

\section{Rozpoznawanie mutyzmu wybiórczego}

Kryteria diagnostyczne mutyzmu wybiórczego zostały ujęte w DSM-5 i prezentują się następująco:

- niemożność mówienia w sytuacjach społecznych (np. w szkole), pomimo ekspresji słownej w innych okolicznościach;

- widoczny wpływ zakłócenia na osiągnięcia szkolne, a potem zawodowe danej jednostki;

utrzymywanie się dysfunkcji przez co najmniej miesiąc;

\footnotetext{
„W rodzinach z zaburzeniami lękowymi często zauważa się nadmierne przywiązanie dzieci do rodziców (lęk separacyjny jest zaburzeniem stosunkowo często współwystępującym u dzieci z SM) oraz nadmierną kontrolę rodzicielską" (Rozenek et al. 2020: 337).

6 Wnikliwej charakterystyki czynników predysponujących, wywołujących i podtrzymujących występowanie mutyzmu selektywnego dokonały Maggie Johnson i Alice Wintgens (Johnson, Wintgens 2016: $36-40)$.
} 
milczenie nie jest spowodowane brakiem wiedzy;

zakłócenia nie można wytłumaczyć występowaniem zaburzeń komunikacji, spektrum autyzmu, schizofrenią i innym zaburzeniem psychotycznym ${ }^{7}$.

Wczesna diagnoza jest podstawą postępowania logopedycznego/neurologopedycznego wobec jednostek z mutyzmem. W pierwszym etapie istotne jest wykluczenie innych zaburzeń, odznaczających się podobnymi objawami (Gałecki, Święcicki 2015: 112). Trudności diagnostyczne wynikają nie tylko z odrzucenia możliwości wystąpienia zaburzeń w aspekcie komunikacji werbalnej. Dylemat diagnosty może mieć źródło w rozpoznaniu mutyzmu selektywnego sprzężonego z innymi współwystępującymi zaburzeniami, np. z fobią społeczną, zespołem Aspergera, uogólnionymi zaburzeniami lękowymi (Kopp, Gillberg 1997: 257-262). W tym celu konieczne jest skoordynowane działanie logopedy z rodzicami, nauczycielami, psychologiem, neurologiem i psychiatrą. Diagnoza skoncentrowana jest głównie na poznaniu specyfiki objawów mutyzmu u konkretnego ucznia, gdyż każde dziecko obarczone tego rodzaju zaburzeniem funkcjonuje w domu i w szkole nieco odmiennie ${ }^{8}$. Istotna jest obserwacja dziecka pod kątem jego zachowań pozawerbalnych, typowych dla mutyzmu wybiórczego: pusty wzrok, sztywne ruchy ciała, brak uśmiechu, unikanie kontaktu wzrokowego, brak spontaniczności, płytka ekspresyjność (Pastuszek-Lipińska et al. 2013: 78). Ostatnim etapem diagnozy jest zaplanowanie działań terapeutycznych, które umożliwią dziecku w wieku wczesnoszkolnym prawidłowy start szkolny, co z kolei ma ogromny wpływ na jego całe życie?

\section{Przypadki kliniczne dzieci z mutyzmem wybiórczym ${ }^{10}$}

\section{Dziewczynka lat 7; vczennica klasy I szkoły podstawowej}

Wywiad: dziewczynka spokojna, bierna, nie sprawiała problemów wychowawczych rodzicom. W szkole nie nawiązywała relacji z rówieśnikami ani z nauczycielami.

Szczegółowe kryteria diagnostyczne zob. (Gałecki, Święcicki 2015: 112).

$8 \quad$ Wg A. Skoczek dzieci, u których zdiagnozowano mutyzm wybiórczy, zazwyczaj odmawiają mówienia w miejscach publicznych, nie rozmawiają z obcymi. Zdarza się jednak, że nie odzywają się także do bliskich członków rodziny (Skoczek 2017a: 31-32).

9 Brak komunikacji werbalnej ogranicza uczenie się oraz wpływa na osiągnięcia edukacyjne ucznia. W przypadku pozostawienia bez pomocy dziecka z mutyzmem skazuje się je na niepowodzenie w realizacji planów życiowych (Smith-Schrandt, Ellington 2018: 14-18).

10 Poniżej opisane zostały dzieci z rozpoznanym mutyzmem selektywnym. Są to przypadki kliniczne pochodzące z praktyki logopedycznej/ neurologopedycznej autorki niniejszego tekstu, która pracuje w Poradni Logopedycznej oraz w Klinice Neurologii UJK Szpitala Specjalistycznego Ducha Świętego w Sandomierzu, prowadząc terapię dzieci i dorosłych z różnymi zaburzeniami mowy. 
Początkowo rodzice nie interweniowali, gdyż byli przekonani, iż spowodowane jest to wejściem dziecka w nowe środowisko.

Badanie logopedyczne: brak wad w budowie anatomicznej narządów mowy, słuch fizyczny oraz fonematyczny w normie. Dziecko w obecności obcych osób nie komunikuje się werbalnie. W gabinecie logopedycznym unika kontaktu wzrokowego, nie wyraża emocji, zachowuje tzw. kamienną twarz.

\section{Chłopiec lat 8; uczeń klasy II szkoły podstawowej}

Wywiad: Podczas rozwoju dziecka matka dostrzegała opóźnienie w zakresie opanowania umiejętności samodzielnego siedzenia (chłopiec zaczął siedzieć około 9. miesiąca życia) i umiejętności chodzenia (chłopiec zaczął chodzić około 14. miesiąca życia). Dodatkowo dziecko zaczęło późno mówić, pierwsze słowa pojawiły się po trzecim roku życia. W pierwszych 4 latach życia cierpiało na dokuczliwe zaparcia oraz chorowało kilkakrotnie na ostre zapalenie krtani. Dziecko często przebywało z babcią ze względu na pracę rodziców. Babcia wykazywała tendencje lękowe w odniesieniu do dziecka, często zabraniała mu różnych zabaw w obawie o jego bezpieczeństwo. Chłopiec, według relacji rodziców, zawsze był grzecznym dzieckiem, ale wycofanym i biernym. W przedszkolu bawił się sam, ale nie dostrzeżono problemów z komunikacją werbalną wobec rówieśników i nauczycieli. Badania przeprowadzone w wieku 6 lat wykluczyły autyzm. W klasie pierwszej dziecko nie kontaktował się z rówieśnikami od początku roku szkolnego. Sytuacja ta nie uległa zmianie nawet po upływie okresu adaptacyjnego, czyli po około miesiącu. Przerwy spędza w klasie, nie chce chodzić na obiady. Nie bawi się z dziećmi w szkole. Nauczyciele zwracają uwagę na sztywność zachowań u chłopca, ciągły niepokój, trudności z werbalnym porozumiewaniem się (zapytany milczy, opuszczając głowę). Nie pojawiają się w szkole żadne komunikaty słowne, nawet zwroty powitalne czy grzecznościowe. W domu nawiązuje kontakt słowny z rodzicami oraz $\mathrm{z}$ młodszym bratem. W obecności rodziców i brata jest wesołym chłopcem.

Badanie logopedyczne: dziecko unika kontaktu słownego i wzrokowego z logopedą. Chowa się za matkę, nie odpowiada na pytania. Widoczne jest zdenerwowanie dziecka, nie chce sięgnąć po żadną z zabawek znajdujących się w gabinecie, pomimo zachęty ze strony logopedy i matki. Chłopiec siedzi nieruchomo, ze spuszczoną głową. Właściwie wskazuje przedmioty na obrazkach. Potwierdza, bądź zaprzecza ruchem głowy w przypadku stawianych przez logopedę pytań zamkniętych. 


\section{Wychodzenie z mutyzmu - terapia logopedyczna}

Najważniejszym celem terapii logopedycznej z dziećmi z mutyzmem wybiórczym jest kształtowanie właściwej postawy społecznej, w tym komunikacyjnej. Dlatego oprócz prowadzenia terapii mowy, konieczna jest systematyczna terapia psychologiczna. Logopeda, a najlepiej neurologopeda powinien wraz z psychologiem opracować sposób porozumiewania się z dzieckiem, by uniknąć utrwalenia postawy niemówienia, a tym samym izolacji społecznej. Wiąże się to z indywidualną pracą z dzieckiem w celu zwiększenia jego pewności siebie oraz uwolnienia go od lęku przed mówieniem. By osiągnąć ten nadrzędny cel, należy mieć na uwadze dążenie do przełamania barier w porozumiewaniu się słownym, które jest możliwe chociażby poprzez stwarzanie sytuacji, w jakich dziecko będzie czuło się swobodnie. Gabinet logopedyczny oraz psychologiczny będą początkowo terenem, w którym dziecko będzie czuło się bezpiecznie. Nie jest to możliwe, jeśli nie zaakceptuje ono siebie i swoich potknięć, błędów, czy wręcz porażek w zawiązywaniu kontaktów z innymi. W realizacji programu logopedycznego niezbędna jest współpraca z rodzicami dziecka oraz z nauczycielami ${ }^{11}$.

W pracy z dzieckiem z SM stosuje się najczęściej behawioralny oraz behawioralno-poznawczy rodzaj terapii (Bergman et al. 2013: 680-689). Dodatkowo wśród metod wspomagających istotną rolę odgrywa systemowa terapia rodzin, muzykoterapia, biblioterapia, arteterapia, teatroterapia, zooterapia i grafoterapia (Skoczek 2017a: 131). Najbardziej znaną techniką behawioralną jest stopniowa desensytyzacja (odwrażliwianie), zwana „sliding in” (wślizgiwanie się) ${ }^{12}$. Technika ta stanowi także podstawę programu terapeutycznego, opracowanego przez Annę Herzyk z myślą o dzieciach dotkniętych mutyzmem. Program zwany jest metodą dziewięciu kroków lub małych kroków, gdyż w zależności od konieczności liczba etapów może ulegać zmianie (od dziewięciu do sześciu). Jest to podejście oparte na wygaszaniu bodźców lękowych z jednoczesną stopniową ekspozycją i desensytyzacją (odczulaniem) (Herzyk 1992: 29; Grzesiak-Witek 2015: 90-91). Początkowo terapeuta mowy/logopeda próbuje dostać się do grona osób, z którymi dziecko komunikuje się słownie. Może to robić w sposób niepostrzeżony dla dziecka, najpierw przebywając w jego domu rodzinnym, potem uczestnicząc w zabawie, ale bez wywierania presji na mówienie. Logopeda stara się, by w pierwszej kolejności dotrzeć do dziecka i nawiązać z nim relacje, po czym wykonuje z nim różne zadania pozajęzykowe, z czasem zwiększając ich rodzaj i stopień

\footnotetext{
11 W terapii mutyzmu selektywnego istotna jest rola całego otoczenia dziecka, a w tym nauczycieli. Szczegółowe wytyczne dla tej grupy zawodowej w odniesieniu do dzieci z SM zostaną zaprezentowane w niniejszym tekście w podpunkcie: „Rola nauczycieli w terapii dziecka z mutyzmem wybiórczym”.

12 Polega ona na stopniowym włączaniu nowej osoby do kontaktu słownego z dzieckiem, stąd określenie „wślizgiwanie się". Istotne jest w tej technice zapewnienie dziecku poczucia bezpieczeństwa oraz wzmacnianie poczucia jego wartości (Cabała et al. 2016: 15-16).
} 
trudności. W zależności od zainteresowań dziecka można modyfikować materiał zadaniowy (np. układanie klocków, ubieranie lalki itp.).

Arteterapia jako rodzaj metody wspierającej stosowanej w terapii mutyzmu wybiórczego pozwala jednostkom z mutyzmem otworzyć się na świat. Niektóre rodzaje arteterapii, tj. muzykoterapia, choreoterapia i plastykoterapia, mają także pozytywny wpływ na osobę dotkniętą mutyzmem: „Niejednokrotnie podopieczny z mutyzmem nie będzie gotów swoich przeżyć i emocji przekazać słowami, ale zrobi to z wykorzystaniem ruchu, rysunku czy muzyki" ${ }^{13}$. Szczególnie cenne jest zastosowanie teatroterapii, czyli terapii przez teatr. Dzieci z mutyzmem chętniej wchodzą w rolę, odtwarzają konkretne postaci, niż tworzą własne wypowiedzi (Grzesiak-Witek 2015: 92).

Rodzice powinni utrwalać z dzieckiem umiejętności nabyte w gabinecie logopedycznym, dotyczące nawiązywania i utrzymywania kontaktów słownych z rówieśnikami. Konieczne jest zabieranie dziecka w miejsca, gdzie mogłoby ono wykorzystać swoje umiejętności. Na początek powinna być to przestrzeń, w jakiej dziecko będzie czuło się bezpiecznie (dom krewnych, zaprzyjaźnionych sąsiadów), a potem plac zabaw, sklep itp. ${ }^{14}$.

\section{Rola nauczycieli w terapii dziecka z mutyzmem wybiórczym}

Nauczyciele odgrywają istotną rolę nie tylko w działaniach terapeutycznych, ale już we wstępnym etapie diagnozy, gdyż to zazwyczaj oni dostrzegają pierwsze trudności ucznia z werbalnym porozumiewaniem się z rówieśnikami i innymi osobami placówki oświatowej. Rodzice nie do końca są świadomi problemów dziecka, które w domu pozostaje aktywne i komunikuje się słownie.

Warto przypomnieć, iż w okresie edukacji wczesnoszkolnej większość przedmiotów prowadzi jeden dydaktyk. Powinien on w odniesieniu do dziecka z mutyzmem wykazać więcej troski i empatii. Wprowadzony w specyfikę trudności i ograniczeń, z jakimi zmaga się uczeń, powinien zadbać o właściwą atmosferę w klasie oraz pozytywne nastawienie rówieśników do cierpiącego na mutyzm kolegi ${ }^{15}$. W dalszym postępowaniu winien on także dążyć do stworzenia warunków dla samodzielnego ini-

\footnotetext{
13 Więcej informacji na temat metod wspierających terapię mutyzmu zob. (Grzesiak-Witek, Sobolewski, Witek 2021).

14 Podczas organizacji terapii mutyzmu wybiórczego logopedzie powinien zawsze towarzyszyć cel, jakim jest umożliwienie dziecku mówienia w okolicznościach i przestrzeni, w których wcześniej prezentowało cechy mutyzmu (Pionek Stone et al. 2002: 168-190).

15 Zdaniem K. Walczykowskiej edukacja nauczycieli odnośnie do postępowania wobec ucznia z SM ma wiodące znaczenie. Brak wiedzy na temat dziecięcego milczenia u wychowawców sprawia, że nieświadomie mogą oni pogłębić mutyzm u podopiecznego (Walczykowska 2006: 42).
} 
cjowania kontaktów przez dziecko. Nauczyciel edukacji wczesnoszkolnej może pomóc dziecku w kształtowaniu umiejętności nawiązywania relacji z rówieśnikami.

Nauczyciel wczesnoszkolny powinien stosować zasadę stopniowania wymagań wobec dziecka. Początkowo mówienie słowa „jestem” podczas sprawdzania listy obecności będzie dla dziecka z SM zadaniem bardzo trudnym. Dopuszczalne jest zatem komunikowanie się gestem podczas porozumiewania się w klasie. Nauczyciel powinien aprobować takie zachowanie ucznia, nie krytykować jego milczenia oraz powstrzymać się od komentowania. Zgoda na niewerbalne odpowiedzi w postaci potwierdzania, bądź zaprzeczania na stawiane pytania zamknięte daje podopiecznemu z mutyzmem poczucie uczestnictwa w dialogu oraz nie wyklucza go z czynnego udziału w lekcji.

Dziecko w pierwszym okresie może czytać na głos tylko w obecności nauczyciela, potem z kolei może czytać fragment wyćwiczonego wcześniej tekstu w otoczeniu kilku znanych mu uczniów, a w końcu w obecności całej klasy. Należy pamiętać, iż umiejętność czytania dla dzieci w początkowych klasach szkoły podstawowej jest umiejętnością dopiero opanowywaną i wymaga licznych ćwiczeń. Podobnie jak samodzielne odczytywanie czytanki przez dziecko wymaga wcześniejszego przetrenowania w obecności samego nauczyciela czy bliskiego kolegi z klasy, tak i samodzielna odpowiedź na lekcji wymaga czasu i wcześniejszego przygotowania.

W metodzie małych kroków, podczas tzw. wślizgiwania się, wychowawca może być osobą, z którą ściśle współpracuje logopeda w celu wprowadzenia dziecka do grupy osób komunikujących się werbalnie. By mógł on spełniać rolę koordynatora, musi nawiązać z uczniem z mutyzmem emocjonalną więź oraz zyskać jego zaufanie. Jego zadanie polegać może na wdrożeniu rówieśnika z klasy do zabawy lub innej aktywności, w jakiej uczestniczy dziecko z SM. Nauczyciel powinien pamiętać, iż dla jego podopiecznego czynnikiem lękotwórczym są nie tylko obce osoby, lecz także nowe miejsca, np. klasa, świetlica. Może on jako gospodarz danej klasy zapoznać dziecko z terenem, objaśnić mu, do czego służą pomoce, pozwolić, by dziecko mogło się oswoić $\mathrm{z}$ daną salą lekcyjną ${ }^{16}$.

Nauczyciel może także pomóc dziecku w redukcji lęku przed szkołą ${ }^{17}$. Dlatego istotne jest, by był on osobą ciepłą i wyrozumiałą. Dziecko z mutyzmem boi się szkoły, oceniania, odpytywania nie dlatego, że jest nieprzygotowane, lecz z powodu swojej wyjątkowej wrażliwości i wspomnianego lęku, który je paraliżuje. Wychowawca wesprze takie dziecko, jeśli będzie używał jasnego języka, zwracając uwagę na to, czy wszyscy uczniowie (w tym jednostka z mutyzmem) zrozumieli przekazywane treści.

\footnotetext{
16 Uwagi na temat roli koordynatora w terapii mutyzmu wybiórczego zob. (Rogowska 2020).

17 Szkoła w oczach dzieci rozpoczynających edukację w klasie pierwszej często jawi się jako obiekt stresu i lęku. Zadaniem nauczyciela edukacji wczesnoszkolnej jest zadbanie o zmianę wizerunku szkoły. Musi on zadbać o to, by lekcje stały się dla uczniów (w tym dla dziecka z SM) przyjemnymi doświadczeniami (Skoczek 2017a: 133).
} 
Dzięki temu pobyt w szkole będzie zaplanowany, bez nagłych niespodzianek, które zburzyłyby poczucie bezpieczeństwa u dziecka z SM. Ważnym elementem w działaniach wychowawcy jest także wyraźne sprecyzowanie zadania domowego (jego istoty i czasu wykonania).

Neurologopeda powinien regularnie przekazywać nauczycielowi wskazówki odnośnie do przeprowadzania technik relaksacyjnych oraz ćwiczeń rozluźniania narządów artykulacyjnych, jakie można stosować w trakcie zabaw czy zajęć lekcyjnych. W przypadku placówki edukacyjnej, w której nie ma zatrudnionego logopedy, nauczyciel edukacji wczesnoszkolnej staje się łącznikiem pomiędzy logopedą a pozostałymi pracownikami szkoły. Podczas spotkania rady pedagogicznej powinien on przedstawić problem dziecka oraz oznajmić, iż milczenie dziecka nie wynika z niechęci, uporu czy manipulacji, lecz jest trudnym zaburzeniem mowy o podłożu lękowym. Wskazane jest także, by przekazał on pozostałym nauczycielom wskazówki odnośnie do postępowania wobec dziecka z SM, jak również zapoznał z propozycjami zajęć grupowych, które mogą być prowadzone w szkole podczas lekcji. Neurologopeda we współpracy z nauczycielem edukacji wczesnoszkolnej powinien opracować ćwiczenia oraz podać przykłady środków dydaktycznych, jakie mogą w szkole stosować dydaktycy, by wspomóc terapię logopedyczną ucznia z mutyzmem.

\section{Zakończenie}

Komunikacja werbalna jest istotnym elementem funkcjonowania człowieka. W sytuacji, gdy pojawią się jakiekolwiek dysfunkcje w tym zakresie, skutkuje to wycofaniem jednostki ze społeczeństwa. Mutyzm wybiórczy jest zaburzeniem trudnym w terapii. W pomoc dziecku poza logopedą, psychologiem musi być zaangażowanych wiele osób z najbliższego środowiska. Nauczyciel edukacji wczesnoszkolnej odgrywa $\mathrm{w}$ tym procesie istotną rolę, dostosowując formy i metody prowadzonych zajęć do dziecka z mutyzmem. Dla sukcesu terapeutycznego znaczenie mają także cechy charakteru wychowawcy. Warto o tym pamiętać, gdyż w szkołach (a szczególnie w klasach I-III) jest coraz więcej dzieci z tego rodzaju ograniczeniami w komunikacji werbalnej.

\section{Bibliografia}

Bergman RL., Gonzalez A., Piacentini J., Keller ML. (2013). Integrated behavior therapy for selective mutism: A randomized controlled pilot study. „Behavior research and therapy”, 51 (10), s. 680-689.

Bilikiewicz A. (red.). (2007). Psychiatria: podręcznik dla studentów medycyny, wyd. 3, Warszawa: Wydawnictwo Lekarskie PZWL. 
Bourne J.E. (2011). Lęk i fobia. Praktyczny podręcznik dla osób z zaburzeniami lękowymi. Kraków: Wydawnictwo Uniwersytetu Jagiellońskiego.

Bystrzanowska M. (2017). Mutyzm wybiórczy - poradnik dla rodziców, nauczycieli i specjalistów. Kraków: Oficyna Wydawnicza Impuls.

Bystrzanowska M. (2018). Terapia logopedyczna dziecka z mutyzmem wybiórczym. Opis i analiza przypadku, [w:] A. Myszka, K. Bieńkowska (red.), Gtos-Jezzyk-Komunikacja. Wobliczu emocji. Rzeszów: Wydawnictwo Uniwersytetu Rzeszowskiego, s. 101-115.

Cabała M., Leśniak-Stępień A., Szot R., Szyszka K. (2016). Mutyzm wybiórczy. Trzy spojrzenia, Kraków: Wydawnictwo Impuls.

Gałecki P., Święcicki Ł. (2015). Kryteria diagnostyczne z DSM-5, tłum. P.S. Krawczyk. Wrocław: Wydawnictwo Edra Urban \& Partner.

Grzesiak-Witek D., Sobolewski P., Witek P. (2021). Dysfunkcje mowy i zaburzenia funkcjonowania spotecznego $w$ chorobach psychicznych. Kielce: Wydawnictwo Uniwersytetu Jana Kochanowskiego w Kielcach (w druku).

Grzesiak-Witek D. (2015). "The piano which speaks”- causes and therapy of child mutism. „Problemy Edukacji, Rehabilitacji i Socjalizacji Osób Niepełnosprawnych”, t. 21, nr 2, s. 85-94.

Herzyk A. (1992). Afazja i mutyzm dziecięcy: wybrane zagadnienia diagnozy i terapii. Lublin: Wydawnictwo Polskiej Fundacji Zaburzeń Mowy.

Janik I. (2012). Mutyzm dziecięcy, [w:] J. Skibska, D. Larysz (red.), Neurologopedia w teorii i praktyce. Wybrane zagadnienia diagnozy i terapii dziecka. Bielsko-Biała: Wydawnictwo Naukowe Akademii Techniczno-Humanistycznej, s. 79-94.

Jonhson M., Wintgens A. (2016). The Selective Mutism Resurce Manual, second edition. UK: Speechmark.

Jóźwiak S., Michałowicz R. (2001). Neurologia dziecięca w praktyce. Lublin: Wydawnictwo Bifolium.

Kokoszka A. (2009). Wprowadzenie do terapii poznawczo-behawioralnej. Kraków: Wydawnictwo Uniwersytetu Jagiellońskiego.

Kopp S., Gillberg C. (1997). Selective mutism: A population - based study: A research note, "Journal of Child Psychology and Psychiatry", nr 38(2), s. 257-262.

Ostergaard K.R. (2018). Treatment of selective mutism based on cognitive behavioural therapy, psychopharmacology and combination therapy - a systematic review, „Nordic Journal of Psychiatry”, 72 (4), s. 240-250.

Pastuszek-Lipińska B. E., Brzostek A., Kamińska-Kolarz B. (2013). Melodic Intonation Therapy - terapia wspierajaca leczenie selektywnego mutyzmu - opis przypadku, „Neuropsychiatria i Neuropsychologia”, nr 8(2), s. 77-83.

Pionek Stone B., Kratochwill T., Sladezcek I., Serlin R.C. (2002). Treatment of selective mutism: A best-evidence synthesis, „School Psychology Quarterly”, nr 17(2), s. 168-190.

Popek L. (2005). Zaburzenia funkcjonowania spotecznego rozpoczynające się $w$ dziecinstwie lub wieku mtodzieńczym, [w:] I. Namysłowska (red.), Psychiatria dzieci i mtodzieży. Warszawa: Wydawnictwo Lekarskie PZWL, s. 139-150.

Rogowska A. (2020). Praca i rola koordynatora $w$ terapii mutyzmu wybiórczego, „Forum Logopedy”, nr 40 https://forumlogopedy.pl/artykul/praca-i-rola-koordynatora-w-terapii-mutyzmu-wybiorczego (dostęp: 30.08.2021). 
Rozenek E.B., Orlof W., Nowicka Z.M., Wilczyńska K., Waszkiewicz N. (2020). Mutyzm wybiórczy - opis zaburzenia i etiologia: czy wybiórczy brak mowy jest zaledwie wierzchotkiem góry lodowej?, „Psychiatria Polska”, nr 54(2), s. 333-349.

Sajewicz-Radke U. (2016). Skale objawowe zaburzeń lękowych. Gdańsk: Pracownia Testów Psychologicznych i Pedagogicznych.

Skoczek A. (2017a). Mutyzm. Zagadnienia teorii i praktyki. Kraków: Wydawnictwo WAM.

Skoczek A. (2017b). Przyczynek w sprawie etiologii mutyzmu, „Neurolingwistyka Praktyczna”, nr 3, s. 31-46.

Smith-Schrandt H.L, Ellington E. (2018). Unable to speak: Selective mutism in youth, „Journal of Psychosocial Nursing and Mental Health Services”, nr 56(2), s. 14-18.

Tarkowski Z. (2017). Mutyzm psychogenny, [w:] Z. Tarkowski (red.), Patologia mowy. Gdańsk: Harmonia.

Tramer, M. (1934). Elektiver Mutismus bei Kindern. „Zeitschrift für Kinderpsychiatrie“, 1, 30-35.

Urbaniuk J. (2008). Dziecko z mutyzmem wybiórczym, [w:] B. Winczura i A. Stawarski (red.), Dzieci chore, niepetnosprawne i z utrudnieniami w rozwoju. Kraków: Oficyna Wydawnicza „Impuls”, s. 455-470.

Walczykowska K. (2006). Mutyzm wybiórczy w praktyce pedagogicznej, „Edukacja i Dialog", nr 3, s. 40-43.

\section{ADRES DO KORESPONDENCJI}

Danuta Grzesiak-Witek

Uniwersytet Jana Kochanowskiego w Kielcach

e-mail: dgrzesiakwitek@ujk.edu.pl 